\title{
ĀRZEMJU STUDENTU MIGRĀCIJAS IETEKME UZ IEDZīVOTĀJU SKAITA SAMAZINĀŠANĀS TENDENCËM LATVIJĀ
}

\author{
Jānis Paiders, Elīna Apsīte-Beriṇa
}

Latvijas Universitāte, G̣eogrāfijas un zemes zinātṇu fakultāte

\begin{abstract}
Anotācija. Latvijas attīstības stratēgija paredz ārvalstu studentu pieplūdumu Latvijā, tas svarīgi arī valsts un privātajām augstskolām, jo tādā veidā iespējams gūt papildus ienākumus un nodrošināt studiju procesu situācijā, kad vietējo studentu skaits ir mazs. Latvijas demogrāfiskās tendences liecina, ka studējošo skaits turpmākajos gados turpinās samazināties. Pašlaik ārvalstu studenti sastāda 8 procentus no studējošo kopskaita, un īpatsvara palielināšanās kompensētu prognozējamo turpmāko vietējo studējošo skaita samazinājumu. Ārvalstu studentu profils ir daudzveidīgs. Pašlaik visvairāk studentu ir no Vācijas, Uzbekistānas, Krievijas un Kazahstānas. Augstskolas nepārtraukti meklē iespējas piesaistīt jaunus studentus no ārzemēm. Vairums ārvalstu studentu koncentrējas Rīgā. Reǵionālajām augstskolām trūkst aktīva mārketinga šo studentu piesaistē un atbilstoša studiju programmu piedāvājuma, kas būtu guvis
\end{abstract}


atzin̄ibu no ārvalstu studentiem. Pētījuma rezultāti parāda, ka ārzemju studentu ietekme uz Latvijas depopulācijas problēmu risināšanu ir neliela.

Atslēgas vārdi: studentu migrācija, ārzemju studenti.

Raksta mērḳis ir analizēt galvenās tendences un raksturlielumus starptautisko studentu migrācijai uz Latviju. Atbilstoši Latvijas Ilgtspējīgās attīstības stratēgijai 2030 (Latvijas Republikas Saeima 2010), ir plānots, ka 2030. gadā ārzemju studenti sasniegs 10\% no kopējā studentu īpatsvara Latvijā. Pēdējo gadu tendences, kuru rezultātā ir ievērojami palielinājies ārzemju studentu skaits, ir padarījušas šo mērḳi par tuvākajā nākotnē sasniedzamu. Tā rezultātā daudzām augstskolām ārzemju studentu piesaiste ir kḷuvusi par nozīmīgu uzdevumu to attīstības stratēǵijā, ḷaujot daḷēji atslogot augstskolas no problēmām, kuras ir izraisījis nepietiekams nozares finansējums un nelabvēlīga demogrāfiskā situācija.

Studējošo skaits Latvijā vislielākais ir bijis 2005./2006. gadā, kopš tā laika pakāpeniski samazinoties par 36\% pēdējo 10 gadu laikā (IZM 2015). Demogrāfiskās tendences liecina, ka studējošo skaits turpmākajos gados turpinās samazināties. Šādos apstākḷos ievērojami palielināsies konkurence starp augstskolām topošo studentu piesaistē, un šie apstākḷi daḷēji izskaidro ārzemju studentu lomas pieaugumu, ārvalstu studentiem daḷēji ḷaujot kompensēt nelabvēlīgās Latvijas demogrāfiskās situācijas tendences.

1. attēls parāda kopējās studējošo skaita pārmaiṇas Latvijā un prognozēto studējošo skaita dinamiku līdz 2025./2026. gadam. Līdzšinējais studējošo skaita kritums ir saistīts ar dzimstības līmeņa samazinājumu Latvijā pēc neatkarības atgūšanas, kā sekas atspoguḷjas studējošo skaita samazinājumā pēc gandrīz 20 gadiem, pēc 1991. gada dzimušie jaunieši beidz vidusskolu. Prognoze par studējošo skaita tendencēm turpmākajos gados ir izveidota, pamatojoties uz Centrālās statistikas pārvaldes pieejamo informāciju par katra gada dzimstību (CSP 2015), kā arī informāciju par studējošo skaita vecumstruktūru (IZM 2015). Izmantojot šo prognozi, var secināt, ka līdz pat 2020. gadam, kad pamatstudiju līmeni noslēdz 1998.-2000. gadā dzimušie jaunieši (viszemākais dzimstības līmenis) ir joprojām paredzams pakāpenisks (mazākā tempā nekā šobrīd) studējošo skaita samazinājums, līdz, iespējams, aptuveni 65000 studējošajiem 2020. gadā. Pēc tam studējošo skaitam atkal būs tendence pamazām palielināties.

Tieši ārvalstu studenti var daḷēji kompensēt prognozējamo turpmāko studējošo skaita samazinājumu. 2014./2015. gadā ārvalstu studenti Latvijā sasniedza 5293 studentus jeb 6\% no kopējā studējošo kopskaita un 2015./2016. gadā pat 8\% no studējošo kopskaita (6 465 ārzemju studenti (IZM, 2015), kas ir ievērojams kāpums pēdējos gados (2007./2008. gadā Latvijas augstskolās tikai 1\% studējošo bija ārzemju studenti). Arī, ņemot vērā ārvalstniekam sarežǵītos nosacījumus, kādā var pretendēt uz mācīšanos valsts finansētajās studiju vietās (eksāmens latviešu valodā), gandrīz visi ārzemju studenti studē par privātajiem līdzekḷiem (vai ES fondu līdzekḷiem apmaiṇas programmās). 


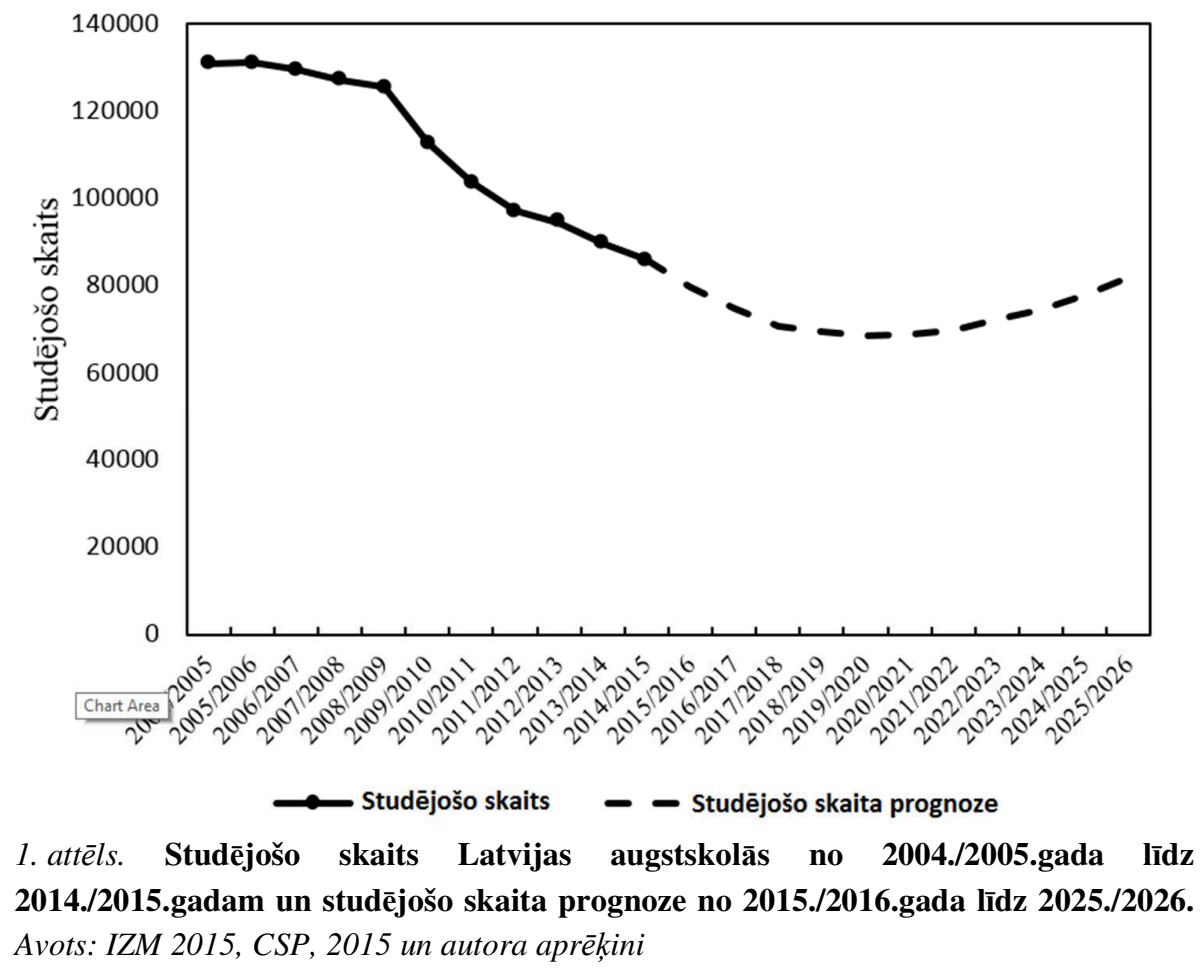

Latvijas augstskolās studējošo ārzemju studentu izcelsmes valstis parāda geogrāfiski dažādo ārzemju studentu profilu (2. attēls). 2014./2015. gadā vislielākais ārzemju studentu skaits ir no Vācijas (842). Vācijas ārzemju studentu skaits pēdējos gados ir ievērojami palielinājies, galvenokārt pateicoties Rīgas Stradiṇa universitātes medicīnas studentu pieplūdumam. Otrs lielākais ārzemju studentu skaits Latvijā ir bijis no Uzbekistānas (seko studenti no Krievijas un Kazahstānas). Bijušo PSRS republiku ārzemju studentu piesaistē, savukārt, ir vērojams vairāku augstskolu aktīvi veiktais mārketings šajās valstīs, kā arī studentu piesaistē palīdz relatîvi zemā studiju maksa, kā arī iespēja mācîties studiju programmās krievu valodā. Kopumā ārzemju studenti Latvijā ir galvenokārt no ES valstīm, ar kurām Latvijai ir spēcīgas vēsturiskas un kultūras saites (Vācija, Zviedrija, Lietuva) un bijušajām PSRS republikām.

Latvijā studējošie ārvalstu studenti veido būtisku dạ̧u no privāto un valsts augstskolu ieņēmumiem. Piemēram, valsts augstskolās ārzemju studentu piesaiste atviegloja 2008. gada finanšu krīzes izraisītās sekas, kad valsts augstākās izglītības finansējums tika samazināts uz pusi. Pateicoties ārzemju studentiem, kuri bieži ir maksas studenti un studē studiju programmās angḷu valodā, kurās mācību maksa ir ievērojami augstāka nekā citās studiju programmās, augstskola varēja turpināt darbību. Paralēli studiju maksai, no kā finansiāli ieguvēji ir augstskolas, ārzemju studenti arī sniedz būtisku finansiālu ieguvumu valstij un sabiedrībai, jo ikdienā tērē naudu dzīvošanai, izklaidei, transportam u.tml. 


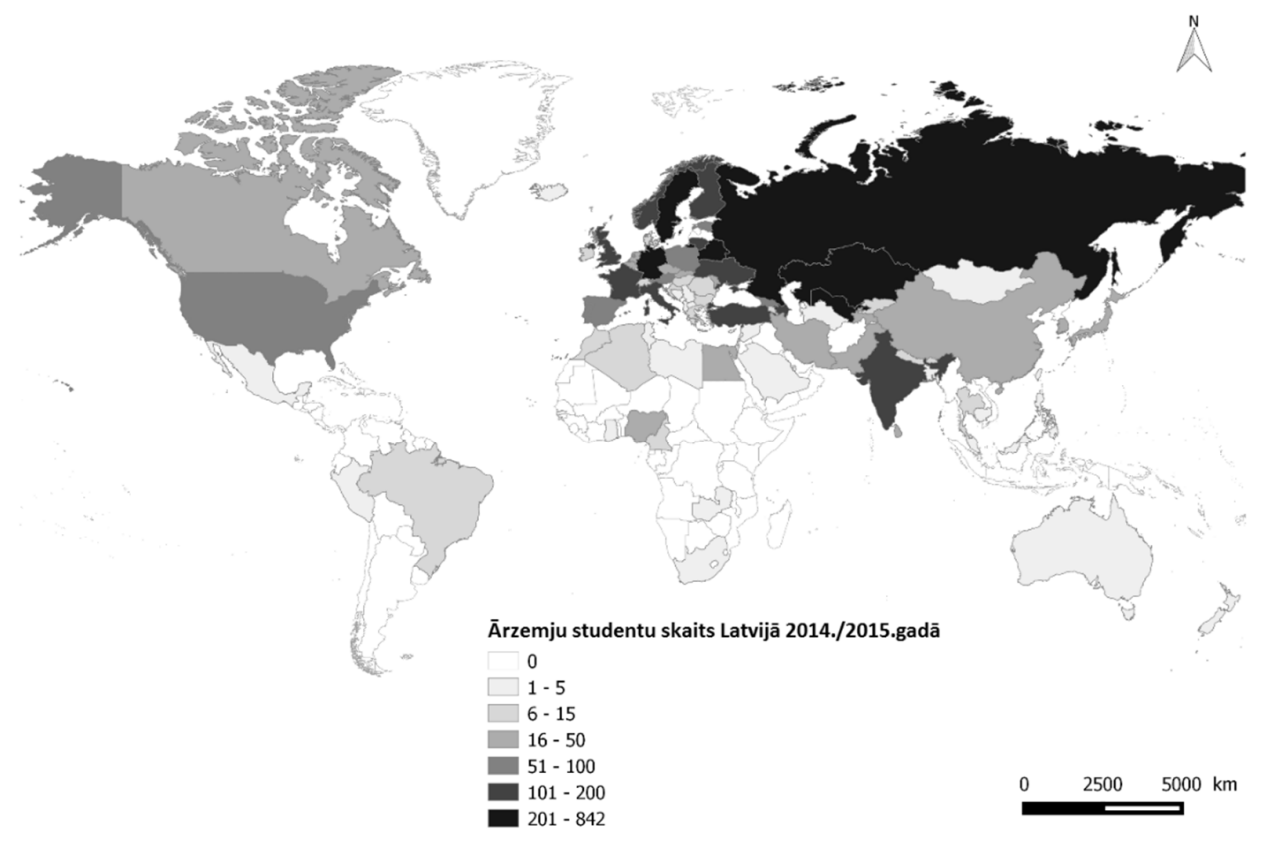

2. attēls. Ārvalstu studentu skaits pēc izcelsmes valsts 2014./2015. gadā. Avots: IZM, 2015 un autora aprēḳini

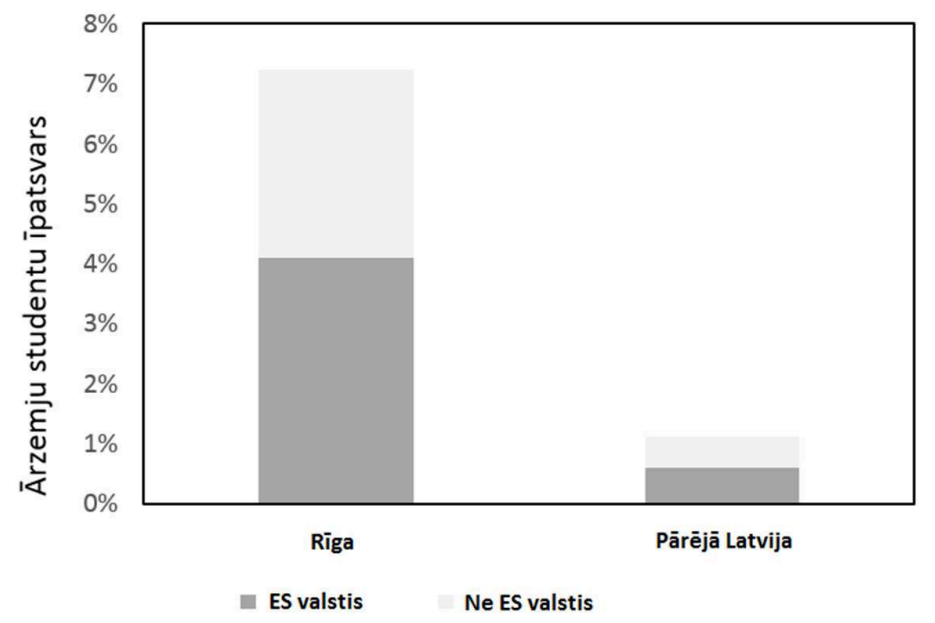

3. attēls. Ārzemju studentu īpatsvars 2014./2015. gadā pēc augstskolas veida. Avots: IZM, 2015 un autora aprēķini

Spēja piesaistīt ārzemju studentus atškiras, vērtējot Rīgas un augstskolas Latvijas reǵionos. Ārzemju studenti sastāda 7,2\% no kopējā studējošo skaita Rīgā, kamēr pārējā Latvijā šis rādītājs 2014./2015. gadā ir vien 1,1\% (3.attēls). Lielo atškirību nosaka dažādi iemesli, bet galvenokārt tas izskaidrojam ar to, ka Rīgas augstskolas ir caurmērā ievērojami lielākas un turīgākas, ar iespējām veikt aktīvāku un apjomīgāku mārketinga kampaņu ārvalstu studentu piesaistē. 2014. gada pētījums par Latvijā studējošo saliedētības veicināšanu un ārzemju studentu diskriminācijas mazināšanu kā otru galveno 
iemeslu, kas ietekmē ārzemju studenta izvēlēto augstskolu un tās studiju programmu, min saṇemtās atsauces no citiem studējošajiem. Tas ḷauj Rīgas augstskolām, kurām ir stabils ārzemju studentu skaits, sniegt citiem potenciālajiem interesentiem informāciju par studiju iespējām un apstākliiem izvēlētajā augstskolā.

Kopumā ārzemju studentu ietekme uz Latvijas depopulācijas problēmu risināšanu ir neliela. Šo studentu piesaiste ir tiešs finansiāls ieguvums augstskolām, kā arī pilsētām, kurās dzīvo šie studenti, jo šo studentu ikdienas tērinu rezultātā radītas darba vietas. Tomēr ārpus Rīgas, kur iedzīvotāju skaita samazinājums ir ievērojami straujāks, augstskolu spēja piesaistīt ārzemju studentus joprojām ir neliela. Aktuāls ir arī jautājums par to, vai ārzemju studentu piesaiste spēs palīdzēt atrisināt nodarbinātības problēmas tajās nozarēs, kurās tuvākajos gados ir plānots ievērojams darba spēka deficīts (Ekonomikas ministrija 2015), taču šis jautājums pieprasa papildus pētījumus šajā jomā.

\section{Atsauces}

Centrālā statistikas pārvalde (CSP). 2015. IDG01. DZIMUŠO SKAITS PĒC DZIMUMA. http://data.csb.gov.lv/pxweb/lv/Sociala/Sociala_ikgad_iedz_dzimst/ ID0010.px/ ?rxid=cdcb978c-22b0-416a-aacc-aa650d3e2ce0 (20.12.15)

Ekonomikas ministrija. 2015. Informatīvais ziṇojums par darba tirgus vidēja un

ilgtermina prognozēm. Ekonomikas ministrija. https://www.em.gov.lv/files /tautsaimniecibas_attistiba/EMZino_150615_full.pdf (15.12.15)

Kārklina, I. 2014. Latvijā studējošo saliedētîbas veicināšana un ārzemju studentu diskriminēšanas mazināšana (2013. gada oktobris - 2014. gada marts). Rīgas Tehniskā Universitāte. http://providus.lv/article_files/2656/original/RTUSP_atskaite_FINAL.pdf?1406891350(10.12.15)

LR Izglītîbas un zinātnes ministrija (IZM). 2015. Statistika par augstāko izglìtību. http://izm.gov.lv/lv/publikacijas-un-statistika/statistika-par-izglitibu/statistika-par-augstakoizglitibu (14.10.15)

Latvijas Republikas Saeima. 2010. Latvijas ilgtspējīgas attīstības stratēǵija „Latvija2030”. http://www.pkc.gov.lv/images/LV2030/Latvija_2030.pdf (14.12.15)

\section{Summary}

The official Latvian Sustainable Development Strategy to 2030 contains a policy goal of increasing the level of international students in Latvia to 10 per cent of the overall student population by 2030 . Achieving this goal will depend on the actions and efforts of individual educational institutions, both state- and privately-funded. Research indicates that international students are attracted to Latvia from diverse locations. Besides specific target countries like Egypt, India and China, there are considerable constant and stable flows from former Soviet countries and other EU countries. Growing the number of international students is very important for both private and state universities, due challenging local demographic trends and associated decreases in local students. Foreign students are also an important source of revenue for institutions of higher education. Whilst the increase in international students generates financial benefits in the short term, the proportion of graduates remaining in Latvia and entering the local labour market is modest. This presents a challenge for policymakers as they seek to maintain and grow the workforce in Latvia. 